M. Assanova*, associate professor ${ }^{l}$

A. Mukhamedzhanova, doctor of economic science, professor $^{2}$

A. Yessengeldina, candidate of economic science, professor ${ }^{2}$

Karaganda Buketov University

Karaganda, Kazakhstan

Academy of Public Administration under

the President of Republic Kazakhstan ${ }^{2}$

Nur-Sultan, Kazakhstan

* - main author (author for correspondence)

e-mail: yanar77@inbox.ru

\title{
IMPACT OF HUMAN CAPITAL ON SUSTAINABLE DEVELOPMENT OF KAZAKHSTAN IN DIGITALIZATION ENVIRONMENT
}

Human capital is the critical resource in the economic growth of Kazakhstan that increases the Gross Domestic Product. Human capital in enhancing sustainable development in the digitalized environment acts as the main social and productive factor in economic growth; it is also a significant provider of knowledge in achieving competitiveness and a sustainable economy in the international market. Human capital allows the generation of knowledge in the digitalized environment. It generates opportunities in the industry to integrate innovative knowledge into its processes, services, and products and disseminate it to the individuals through giving information, training, and competence in education.

The primary significance of skilled workers, competencies, and knowledge is increasing and growing due to the definite features of the services and products offered by human capital in the digital environment. Human capital is not always accentuated when assessing sustainable development in the digitalized environment, but human capital is the significant factor. In various countries, the competitiveness of human capital in digitalized environments is inferior to anticipated, providing prospects for additional investment in affordability through better labor and education market practices.

The study will analyze the leading indicators of sustainable development to the industries and consider the potentialities of human capital as the critical factor in determining growth and sustainable development in a digitalized environment. It also contemplates the promising areas of development and research in the digital economy initiated by human capital, identifies the conforming problems in the growth and the role of human capital in Kazakhstan in sustainable development in the digitalized environment, and analyzes the issues. The main influential aspects of the living standards of residents existing in rural extents are determined. As an effect of the review, the writers articulate the primary responsibilities for supplementary perusing the impact of human capital on the sustainable development of Kazakhstan's underdeveloped zones and evolving a systematically grounded structural and economic instrument for its growth, taking into justification practical outcomes.

Keywords: sustainable development, human capital, digital economy, technological and scientific development, transformation, digital technology, employee skills, technology, digital environment, competitiveness.

Кілт сөздер: тұрақты даму, адами капитал, иифрлық экономика, технологиялық және вылыми даму, трансформация, ицфрлық технологиялар, қызметкерлердің давдылары, технологиялар, иифрлық орта, бәсекеге қъабілеттілік.

Ключевые слова: устойчивое развитие, человеческий капитал, иифровая экономика, технологическое и научное развитие, трансформация, цифровые технологии, навыки работников, технологии, иифрровое окружение, конкурентоспособность.

JEL classification: J24, J41

Introduction. Presently, the international calamities have uncovered the complications of the agricultural segment of Kazakhstan. In this respect, the prime errands of expanding agricultural production necessitate significant explanations, particularly the duty of generating proficient human capital, pricing policies, and usage. The current condition in rural areas is connected with the deflation of agronomic labor, the flagging of its enthusiasm among the inhabitants, and similarly 
with a low ordinary of living. All these aspects are blocks to the justifiable development of rural ranges. The function of human capital and its progress, as among the key influences in establishing sustainable development of rustic terrains, is appropriate and entails vigilant study and expansion of a technically built organizational and fiscal mechanism. Subjects of productive engagement, refining the superiority and living standard, development of social infrastructure and transport - all this is a neutral depiction of the current condition of rural parts of Kazakhstan, which are not intelligent to explain on their own without the appropriate and complete national sustenance.

The current models of fiscal development internationally directly move the revolution in the character of the person, who is the goal and subject of production in humanity, as fine as an imperative constituent of improvement in the country and society's economy [1]. A person is a fundamental basis and symbol of development in any production course, as it conveys irreplaceable information and experience that permits it to reinforce, as well as adding worth owing to its exceptional physiological and logical data-examining the understanding in the expertise of developed republics, the program towards an acquaintance economy, which contains the aptitude of an individual to generate pioneering products and tactics, energy-saving skills, which eventually bring enormous revenues. Thus, human capital develops the source for any course's justifiable and cohesive progress in civilization and production.

Methodology. As an operational approach, a systematic approach is used, within which rational, numerical analysis, and amalgamation are delivered. In the study of the sustainable development condition and tendencies of the economic Digitalization of Kazakhstan, experiential universal scientific systems of perception were used [2]. The technique of collection and observation of evidence made it probable to evaluate the current state of communication and statistical technologies in the Democracy of Kazakhstan to recognize the standing problems. The sequencer "Digital Kazakhstan" was applied as a pragmatic factual [3].

In the course of scientific examination, approaches of intelligent technology, relative, relationship, factor scrutiny, expert approximations, monographic systems were used. In direction to attain a satisfactory level of human capital in agron- omy and economic growth, in our view, it is essential to carry out procedures to advance. Systemic contrivance procedures are casing all its basic elements: enlightening, social, ethical, communal, economic, and others.

Literature review. After scrutinizing the perception of "human capital" in the errands of several economists and scientists, we recognized some of the significant concepts. Human capital is a stock of knowledge, skills, and motivation [4].

According to Janshanlo et al. 2020. pp.81-92) defines human capital as a source of future gratification and future earnings. It is said to be human since it is an integral part of human living [5]. T. Schultz argues that human capital is a form of acquired skills or congenital, reinforced by suitable investments. V Schetinin deliberates skills in industry activity, motivation, mobility, physical condition, knowledge, and natural abilities. Based on the preceding, it can be settled that acquired knowledge and skills and innate talents and skills are the main factors that affect the evolutionary development of human capital [6].

During the public Presidential Speech to the individuals of Kazakhstan, "New Development Prospects under the Fourth Business Revolt," human capital is designated in the seventh urgency track of the country's development. Even throughout the presence of the Soviet Union, the Kazakh SSR was a democracy that produced agronomic goods [7]. Most of the land in the Republic of Kazakhstan was accounted for almost 200 million hectares which denote $80 \%$ of the nation's land. Kazakhstan is one of the principal manufacturers and exporters of such critical products as flour and cereals, and the republic is among the world's bests in auctions of flour export. The core principle of the long-term progress of each discrete country is to gratify the wants and ambitions of individuals and society. One of the significant circumstances for sustainable development is to accomplish the gratification of the fervent desires of each person and the whole community, as well as the practicing to provide every person with an equal opportunity [8]. Human capital allows the generation of knowledge in the digitalized environment. It provides opportunities in the industry to integrate its innovative knowledge into its processes, services, and products and disseminate it to the individuals through giving information, training, and competence in education. 


\section{Экономика}

Human capital does not only allow the generation of knowledge in the digitalized environment but also provides generating opportunities in the industry in integrating its innovative knowledge to its processes, services, products and disseminating it to the individuals through giving information, training, and competence in education [9].

Main part. Discussion. Human capital is focused in every bit as a significant element of sustainable development as is the corporeal environment, both since human capital is the foremost basis of economic progress in contemporary economies and because that investment can criticize and become antiquated in a similar way as corporal or perceptible. Economic growth and Human capital have a sturdy connection. Human capital marks economic evolution and can support to advance of an economy by intensifying the skills and knowledge of its persons. The skills deliver financial worth since conversant personnel can lead to amplified productivity. It is beneficial to discriminate between various kinds of capital: social, human, natural, produced, and financial. All are shares that have the volume to yield streams of economically necessary outputs. The preservation of all five varieties of capital is indispensable for the sustainability of financial development [10].

According to Chulanova,2017. pp.23-31). One of the primary environments for large-scale management reserves in the application of digital technologies and human capital is the valuation of the influence of practical actions on economic progress in terms of cost-benefit fractions. Irrespective of sustainable economic development, assurances of a satisfactory return on such savings are obligatory to validate the probability of their execution. The most significant effect of human capital on Digitalization can be accomplished in high-technology divisions of the facility sector and high-tech productions, the usefulness of which can rise at a quicker skip than other economic sectors [11].

According to Khan, Human capital and Digitalization will entail not only advance in investments in digital skills but also a fundamental transformation of the infrastructure of virtually all segments of the economy (with the exclusion of the extracting divisions, where this procedure has previously arisen to a large degree), which ensures high development rates of the involvement of the capital aspect to rate added [12]. In several economic sectors, the invasion of highly competent and skilled staff will not be intelligent to reward for the proclamation of low-skilled employees, which will result in a negative influence of the employment factor to the development charges of discrete parts of the economy. The critical element in the success of sustainable development and digitalization courses is the accessibility of highly skilled personnel inadequate capacities and appropriate occupations, as well as a teaching scheme for authorities with confident aptitudes for the development and enactment of digital skills while placing human capital in use to enhance proper and critical allocation which will give rise and growth to the economy as a whole [13]. (Figure 1).

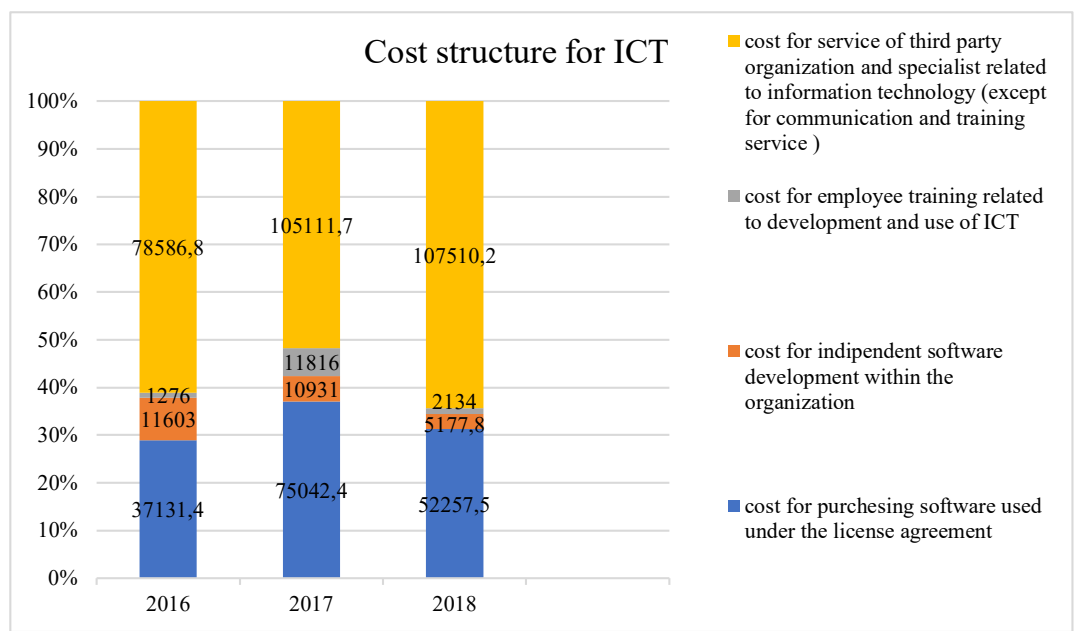

Figure 1. Cost structure for ICT in Kazakhstan in the period 2016-2018 
The transition to a digital economy while using human capital is meaningfully shifting the labor market. Laterally, with the feast of evidence know-how in all extents of life, numerical skills are fetching critically imperative from the opinion of view of proprietors [14]. A large-scale revolution of rations for experts is anticipated since various actions that have not remained pretentious by prior waves of the digital skills adoption can be mechanized in the adjacent future. The significant aptitude that governs the competitive compensations of the corporations of the upcoming is big data analytics and the universal link between precise segments of the economy and higher enlightenment. The aptitude to labor with vast displays of designed and shapeless material can expand the eminence of forecasting the demand, enhance processes [15].

Conclusion. Human capital covers as the primary basis for the sustainable and unified development of any procedure in production and society in a digitalized environment. Two significant factors influence and determine growth and advancement in Human capital: acquired knowledge and skills and innate talents and abilities. The present stage of expansion of rural grounds is manifested by the escalation of the procedure of growing the quality and level of life of the people, the transformation of the socio-economic set-up of the community, which offers rural inhabitants in villages that encounter modern ideals of the eminence of life heightened by delivery of sufficient human capital. The function of human capital and its progress, as among the key influences in establishing sustainable development of rustic terrains, is appropriate and entails vigilant study and expansion of a technically built organizational and fiscal mechanism. Human capital is the significant determinant of long-term efforts and sustainability to accelerate the consciousness of human evolution and mentally self-cognizant emergence, which will make people more effective in their approaches hence ensuring a sustainable future of the economy.

At present, there is a tendency to grow disparities in the living ideals of the people in the urban and the country; there are meaningful variances in revenue by section. Nevertheless, there is an extra delinquent - low interest in high-value agricultural teaching on the fragment of scholars. The main motive for this is the collegial level of earnings in contrast with other commerce, embryonic infrastructure in the country, unclear occupation projections, high sensual activity, and problematic working settings. Only the amalgamation of exertions of the science, state, business, and local government can take rural zones onto the route of workable socio-economic development. The evolution probable of human capital is open-source; its coherent use and active management in the long term can distress the more development of the agro-industrial composite of the Democracy of Kazakhstan.

\section{REFERENCES}

1. Ospanov A.A. Development of innovation in the framework of the industry 4.0 in the republic of Kazakhstan // The latest research in modern science: experience, traditions and innovations. - 2018. - C. 73-75.

2. Kalymbek B. et al. The Effect of Digitalization on Environmental Safety //Journal of Environmental Management \& Tourism. - 2021. - T. 12. - №. 5. - C. 1299-1306.

3. Agumbayeva A. Y. et al. Industrial transformation of Kazakhstan in digitalization's era // J. Advanced Res. L. \& Econ. - 2019. - T. 10. - C. 1861.

4. Alibekova G. et al. Digital transformation enablers and barriers in the economy of Kazakhstan // The Journal of Asian Finance, Economics, and Business. - 2020. - T. 7. - №. 7. - C. 565-575.

5. Janshanlo R. E. et al. The content and role of human capital in the modern economy of Kazakhstan // Human Systems Management. - 2020. - T. 39. - №. 1. - C. 81-92.

6. Bespalyy S. V. et al. Sustainable Development of a Region. Case Study-Kazakhstan // Journal of Environmental Management and Tourism (JEMT). - 2021. - T. 12. - №. 02 (50). - C. 529-537.

7. Chulanova Z. K. The human capital as a factor of competitiveness and economic development // The Journal of Business Economics and Environmental Studies. - 2017. - T. 7. - №. 3. - C. 23-31.

8. Jianzhong X. U., Assenova A., Erokhin V. Renewable energy and sustainable development in a resource-abundant country: Challenges of wind power generation in Kazakhstan // Sustainability. 2018. - T. 10. - №. 9. - C. 3315. 


\section{Экономика}

9. Zhunusov B. et al. Improving Human Capital Competitiveness in Rural Areas of Kazakhstan // Advances in Social Science, Education and Humanities Research. - 2019. - T. 393. - C. 295-299.

10. Gekht I., Philippov D., Saidov A. The Dual System Efficiency of Human Capital Formation of the Republic of Kazakhstan Agroindustrial Complex // Ecological Agriculture and Sustainable Development Editors, South Ural State University. - 2019. - C. 149-156.

11. Zhanbayev R., Sagintayeva S., Abildina A. Digitalization of the Economy of Kazakhstan as a Factor of Innovative Development // 2nd International Scientific and Practical Conference "Modern Management Trends and the Digital Economy: from Regional Development to Global Economic Growth"(MTDE 2020). - Atlantis Press, 2020. - C. 966-971.

12. Khan M. CO2 emissions and sustainable economic development: New evidence on the role of human capital //Sustainable Development. - 2020. - T. 28. - №. 5. - C. 1279-1288.

13. Sokira T. Human capital as a vector of modernization of the economy of Kazakhstan // Vestnik KazNU. Serya Economicheskaya. - 2018. - T. 123. - №. 1. - S. 78-86 [in Russian].

14. Gaziz S. et al. Digital economy and its role in the process of economic development // Journal of Security \& Sustainability Issues. - 2020. - T. 9. - №. 4.

15. Baigelova A. N. Digitalization in the development of human capital as a condition for competitiveness and economic growth of the republic of Kazakhstan // Научный журнал «Доклады НАН РК». - 2020. - №. 2. - C. 107-113.

\section{ЛИТЕРАТУРА}

1. Ospanov A.A. Development of innovation in the framework of the industry 4.0 in the republic of Kazakhstan // The latest research in modern science: experience, traditions and innovations. - 2018. - C. 73-75.

2. Kalymbek B. et al. The Effect of Digitalization on Environmental Safety//Journal of Environmental Management \& Tourism. - 2021. - T. 12. - №. 5. - C. 1299-1306.

3. Agumbayeva A. Y. et al. Industrial transformation of Kazakhstan in digitalization's era // J. Advanced Res. L. \& Econ. - 2019. - T. 10. - C. 1861.

4. Alibekova G. et al. Digital transformation enablers and barriers in the economy of Kazakhstan // The Journal of Asian Finance, Economics, and Business. - 2020. - T. 7. - №. 7. - C. 565-575.

5. Janshanlo R. E. et al. The content and role of human capital in the modern economy of Kazakhstan // Human Systems Management. - 2020. - T. 39. - №. 1. - C. 81-92.

6. Bespalyy S. V. et al. Sustainable Development of a Region. Case Study-Kazakhstan // Journal of Environmental Management and Tourism (JEMT). - 2021. - T. 12. - №. 02 (50). - C. 529-537.

7. Chulanova Z. K. The human capital as a factor of competitiveness and economic development // The Journal of Business Economics and Environmental Studies. - 2017. - T. 7. - №. 3. - C. 23-31.

8. Jianzhong X. U., Assenova A., Erokhin V. Renewable energy and sustainable development in a resource-abundant country: Challenges of wind power generation in Kazakhstan // Sustainability. 2018. - T. 10. - №. 9. - C. 3315.

9. Zhunusov B. et al. Improving Human Capital Competitiveness in Rural Areas of Kazakhstan // Advances in Social Science, Education and Humanities Research. - 2019. - T. 393. - C. 295-299.

10. Gekht I., Philippov D., Saidov A. The Dual System Efficiency of Human Capital Formation of the Republic of Kazakhstan Agroindustrial Complex // Ecological Agriculture and Sustainable Development Editors, South Ural State University. - 2019. - C. 149-156.

11. Zhanbayev R., Sagintayeva S., Abildina A. Digitalization of the Economy of Kazakhstan as a Factor of Innovative Development // 2nd International Scientific and Practical Conference "Modern Management Trends and the Digital Economy: from Regional Development to Global Economic Growth"(MTDE 2020). - Atlantis Press, 2020. - C. 966-971.

12. Khan M. CO2 emissions and sustainable economic development: New evidence on the role of human capital //Sustainable Development. - 2020. - T. 28. - №. 5. - C. 1279-1288.

13. Сокира T. Human capital as a vector of modernization of the economy of Kazakhstan // Вестник КазНУ. Серия Экономическая. - 2018. - Т. 123. - №. 1. - С. 78-86. 
14. Gaziz S. et al. Digital economy and its role in the process of economic development // Journal of Security \& Sustainability Issues. - 2020. - T. 9. - №. 4.

Baigelova A. N. Digitalization in the development of human capital as a condition for competitiveness and economic growth of the republic of Kazakhstan // Научный журнал «Доклады НАН РК». - 2020. - №. 2. - C. 107-113.

\title{
М.К. Асанова, А.Г. Мухамеджанова, А.С. Есенгельдина ЦИФРЛАНДЫРУ ЖАҒДАЙЫНДА ҚАЗАҚСТАННЫН ТҰРАҚТЫ ДАМУЫНА АДАМИ КАПИТАЛДЫН ӘСЕРІ
}

\begin{abstract}
Андатпа
Адами капитал жалпы ішкі өнімді ұлғайтатын Қазақстанның экономикалық өсуінің маңызды ресурсы болып табылады. Цифрлық ортада тұрақты дамуды қамтамасыз етудегі адами капитал экономикалық өсудің негізгі әлеуметтік және өндірістік факторы ретінде әрекет етеді және ол сонымен қатар халықаралық нарықта бәсекеге қабілеттілік пен тұрақты экономикаға қол жеткізу үшін маңызды білім көзі болып табылады. Адами капитал сандық ортада білім алуға мүмкіндік береді. Бұл салада инновациялық білімді өз процестеріне, қызметтері мен өнімдеріне біріктіруге және ақпаратты ұсыну, оқыту және білім беру құзыреттілігі арқылы жеке тұлғаларға таратуға мүмкіндік береді.

Білікті жұмысшылардың, құзыреттер мен білімнің маңызы цифрлық ортада адами капитал ұсынатын қызметтер мен өнімдердің белгілі бір ерекшеліктеріне байланысты артып, өсуде. Адами капитал цифрлық ортадағы тұрақты дамуды бағалау кезінде әрдайым назар аудармайды, бірақ адами капитал маңызды фактор болып табылады. Әр түрлі елдерде цифрлық ортадағы адами капиталдың бәсекеге қабілеттілігі күтілгеннен төмен, бұл еңбек нарығы мен білім беру тәжірибесін жақсарту арқылы қол жетімділікті арттыруға қосымша инвестициялар үшін перспективалар ашады.

Зерттеуде өнеркәсіп салаларының тұрақты дамуының жетекші көрсеткіштері талданады және цифрлық ортадағы өсу мен тұрақты дамуды айқындайтын маңызды фактор ретінде адами капиталдың мүмкіндіктері қарастырылады. Онда сондай-ақ адами капитал бастамашылық еткен цифрлық экономикадағы даму мен зерттеулердің перспективалық бағыттары қаралады, цифрлық ортада тұрақты дамудағы Қазақстандағы адами капиталдың өсуі мен рөліндегі тиісті проблемалар айқындалады, сондай-ақ проблемалар талданады. Ауылдық жерлерде тұратын тұрғындардың өмір сүру деңгейінің негізгі әсер етуші аспектілері анықталды. Шолу нәтижесінде авторлар адами капиталдың Қазақстанның дамымаған аймақтарының тұрақты дамуына әсерін қосымша зерттеу және практикалық нәтижелердің негіздемесін ескере отырып, оның өсуі үшін жүйелі негізделген құрылымдық және экономикалық құралды әзірлеу бойынша негізгі міндеттерді тұжырымдайды.
\end{abstract}

\section{М.К. Асанова, А.Г. Мухамеджанова, А.С. Есенгельдина \\ ВЛИЯНИЕ ЧЕЛОВЕЧЕСКОГО КАПИТАЛА НА УСТОЙЧИВОЕ РАЗВИТИЕ КАЗАХСТАНА В УСЛОВИЯХ ЦИФРОВИЗАЦИИ}

\begin{abstract}
Аннотация
Человеческий капитал является важнейшим ресурсом экономического роста Казахстана, который увеличивает Валовой внутренний продукт. Человеческий капитал в обеспечении устойчивого развития в цифровой среде выступает в качестве основного социального и производственного фактора экономического роста; он также является важным источником знаний для достижения конкурентоспособности и устойчивой экономики на международном рынке. Человеческий капитал позволяет генерировать знания в цифровой среде. Это создает возможности в отрасли для интеграции инновационных знаний в свои процессы, услуги и продукты и распространения их среди отдельных лиц посредством предоставления информации, обучения и компетентности в области образования.

Первостепенное значение квалифицированных работников, компетенций и знаний возрастает и растет в связи с определенными особенностями услуг и продуктов, предлагаемых человеческим капиталом в цифровой среде. Человеческий капитал не всегда акцентируется при оценке устойчивого развития в цифровой среде, но человеческий капитал является важным фактором. В различных странах конкурентоспособность человеческого капитала в цифровой среде ниже ожидаемой, что открывает перспективы для дополнительных инвестиций в повышение доступности за счет улучшения практики рынка труда и образования.
\end{abstract}




\section{Экономика}

В исследовании будут проанализированы ведущие показатели устойчивого развития отраслей промышленности и рассмотрены возможности человеческого капитала как важнейшего фактора, определяющего рост и устойчивое развитие в цифровой среде. В нем также рассматриваются перспективные направления развития и исследований в цифровой экономике, инициированные человеческим капиталом, выявляются соответствующие проблемы в росте и роли человеческого капитала в Казахстане в устойчивом развитии в цифровой среде, а также анализируются проблемы. Определены основные влияющие аспекты уровня жизни жителей, проживающих в сельской местности. В результате обзора авторы формуи экономического инструмента для его роста с учетом обоснования практических результатов.

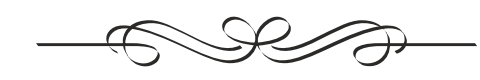

